\title{
Forage Diversity and Dietary Selection by Wintering Mule Deer
}

\author{
L.H. CARPEN'TER, O.C. WALLMO, AND R.B. GILL
}

\begin{abstract}
During a 30-day grazing trial, six mule deer (Odocoileus hemionus hemionus) at pasture altered their food selection significantly as availability of forage changed. At the beginning of the trial when forbs and grasses were abundant, they comprised better than $50 \%$ of the diet; but by the end of the trial when these preferred forages were less abundant, grass and forb declined. Shrub use increased and forb and grass use decreased as snow depths increased. Kesults support the conjecture that big sagebrush (Artemisia tridentata wyomingensis) in excess of $30 \%$ in the diet is detrimental to mule deer nutritional health.
\end{abstract}

Empirical experience with domestic livestock (Cook and Harris 1968; Galt et al. 1969) and some research results suggest that availability of a variety of forages improves herbivore nutrition. Several published accounts offer field observations in support of this contention with respect to the welfare of deer (Leach 1956; Trout and Thiessen 1968; Wallmo and Regelin in press). As a result of feeding experiments, some researchers suggest that deer fare better when native forages are fed in combination or with cultivated hay, than when fed alone (Dietz and Yeager 1959; Gill 1972; Ullrey et al. 1971), but there is no other experimental evidence to support the hypothesis. The present paper presents information on forage availability and forage selection by deer in a small pasture on big sagebrush (Artemisia tridentata wyomingensis) winter range in north central Colorado

\section{Methods}

The pasture, $6 \mathrm{~km}$ southeast of Kremmling, Colo., was 2.18 ha in size $(108 \times 202 \mathrm{~m})$. It was stocked with three male and three female mule deer, all yearlings (18-19 months old), for 30 days. They were introduced to the pasture on January 19, 1972, the 7th day of a 10-day period of transition from their pen ration (alfalfa pellets and hay offered $a d$ lib.) plus native forage, to native forage alone. For 13 days prior to January 19 , they had been exposed to the same forage species in two other pastures. During the first 4 days in the 2.18-ha pasture, they received decreasing amounts of concentrate (from 0.5 to 0.2 $\mathrm{kg} /$ deer/day). The stocking rate, 83 deer-days/ha, is in the range observed for wild deer on open range in the vicinity.

Carpenter and Gill are, respectively, wildlife researcher, Kremmling, and big game research leader, Colorado Division of Wildlife, Fort Collins. Wallmo is principal wildlife biologist, U.S. Forest Service Forestry Sciences Laboratory, Juneau, Alaska.

Colorado Division of Wildlife Operations were conducted under Pitman Robertson Project W-38-R.

The authors gratefully acknowledge Don Reichert for his field assistance and Larry Strong for his assistance in drafting figures.

Manuscript received June 10, 1978.
Standing crop of herbage was estimated at the end of the preceding growing season (August 1971) with double-sampling procedures (Carpenter 1976). Four-hundred fifty quadrats, each $30 \times 61 \times 46$ $\mathrm{cm}$, width $\times$ length $\times$ height, were read with an electronic capacitance meter (Neal and Neal 1973; Carpenter et al. 1973). Ninety of the quadrats were clipped to provide a regression of herbage weights on meter readings in order to use the larger sample to estimate herbage biomass. Current annual growth was clipped from all portions of shrub crowns which occurred on the clip plots. Few shrubs exceeded the $46 \mathrm{~cm}$ height limitation of the meter and their contribution to overall forage yields was considered insignificant. These estimates indicated there were approximately $1,945 \mathrm{~kg}$ (oven-dry) of shrub current annual growth and $900 \mathrm{~kg}$ of grass and forb herbage in the pasture at the end of the previous summer. Big sagebrush made up over $95 \%$ of the annual shrub yield. Other shrub forage included in order of abundance, were stems of serviceberry (Amelanchier alnifolia) snowberry (Symphoricarpos oreophilus), and green rabbitbrush (Chrysothamnus viscidiflorus)—all deciduous shrubs. Grasses made up $85 \%$ of the herbaceous vegetation. The most abundant was bluebunch wheatgrass (Agropyron spicatum), with pine needlegrass (Stipa pinetorum) second in abundance. At least seven other species were common, including western wheatgrass (Agropyron smithii), mutton bluegrass (Poa fendleriana), bluegrama (Bouteloua gracilis), bottlebrush squirreltail (Sitanion hysterix), prairie Junegrass (Koeleria (ristata), and needleandthread grass (Stipa comata). The most abundant forb was a recumbent, perennial phlox (Phlox bryoides) which typically maintains green leaves through winter. Three other species classified as forbs-fringed sage (Artemisia frigida), buckwheat (Eriogonum umbellatum), and mat penstemon (Penstemon caespitosus) - provided very small amounts of green foliage. Several other infrequent forbs were present only as dead stems of annual growth.

During early morning and late afternoon on each day of the 30-day grazing study, forage selection of one to three of the deer was observed. The number of bites (one apparent gathering of food) taken of each plant species was recorded as described by Wallmo et al. (1972). Observation periods lasted as long as the deer grazed intently. Seventy-eight such deer "meals" were observed, averaging 75 minutes in duration (range 16-126 min) and 928 bites per meal $(72,351$ total bites). Portions of at least 28 species were eaten (some ingested material was unidentifiable), including four shrubs, 11 or more grasses, 10 or more forbs, and three lower plants (two lichens, one moss). Eleven species contributed $1 \%$ or more to the total bites (Table 1).

The deer were weighed on January 19 and 26, February 2, 9, 13, and 17. The deer, ranging from 41 to $71 \mathrm{~kg}$, weighed a total of $337 \mathrm{~kg}$ on January 19. At a mean forage intake rate of $17 \mathrm{~g} / \mathrm{kg} /$ day of air-dry forage (Alldredge et al. 1974), they could have consumed approximately $172 \mathrm{~kg}$ of forage over the entire grazing period, or about $6 \%$ of the herbage present. In a similar pasture nearby, the intake rate of deer of the same age was estimated to average $15.6 \mathrm{~g}$ oven-dry forage $/ \mathrm{kg} /$ 
Table 1. Major components of recorded mule deer diets for a 30-day period. (Jan. 19-Feb. 17, 1972) in a 2.18-ha pasture on big sagebrush winter range.

\begin{tabular}{lccc} 
Species & Symbol & $\begin{array}{c}\text { Bites/day } \\
( \pm \mathrm{SE})\end{array}$ & $\begin{array}{c}\text { Percentage } \\
\text { total bites }\end{array}$ \\
\hline $\begin{array}{l}\text { Agropyron spicatum } \\
\text { Artemisia tridentata }\end{array}$ & Agsp & $1049 \pm 112$ & $43.4^{\mathrm{a}}$ \\
$\quad$ wyomingensis & $\mathrm{Artr}$ & $311 \pm 56$ & 13.0 \\
Phlox bryoides & $\mathrm{Phbr}$ & $209 \pm 45$ & 8.7 \\
Stipa pinetorum & $\mathrm{Stpi}$ & $133 \pm 22$ & $5.5^{\mathrm{a}}$ \\
Agropyron smithii & $\mathrm{Agsm}$ & $78 \pm 16$ & $3.2^{\mathrm{a}}$ \\
Poafendleriana & $\mathrm{Pofe}$ & $67 \pm 21$ & $2.8^{\mathrm{a}}$ \\
Amelanchieralnifolia & Amal & $65 \pm 18$ & 2.7 \\
Symphoricarpos oreophilus & Syor & $47 \pm 14$ & 1.9 \\
Chrysothamnus viscidiflorus & Chvi & $47 \pm 17$ & 1.9 \\
Bouteloua gracilis & Bogr & $39 \pm 12$ & 1.6 \\
Artemisiafrigida & Arfr & $26 \pm 7$ & 1.1 \\
\hline
\end{tabular}

"Lnidentified grasses. $10.2 \%$ of total, may have included some of these species.

day (Carpenter and Baker 1975).

Snow depths were measured along systematically located sampling points throughout the pasture. Measurements were made on six ditferent dates over the 30-day trial. Snow depth was measured whenever an obvious change had occurred.

\section{Results}

Composition of the observed diets of the deer changed dramatically from the beginning to the end of the study (Fig. 1).

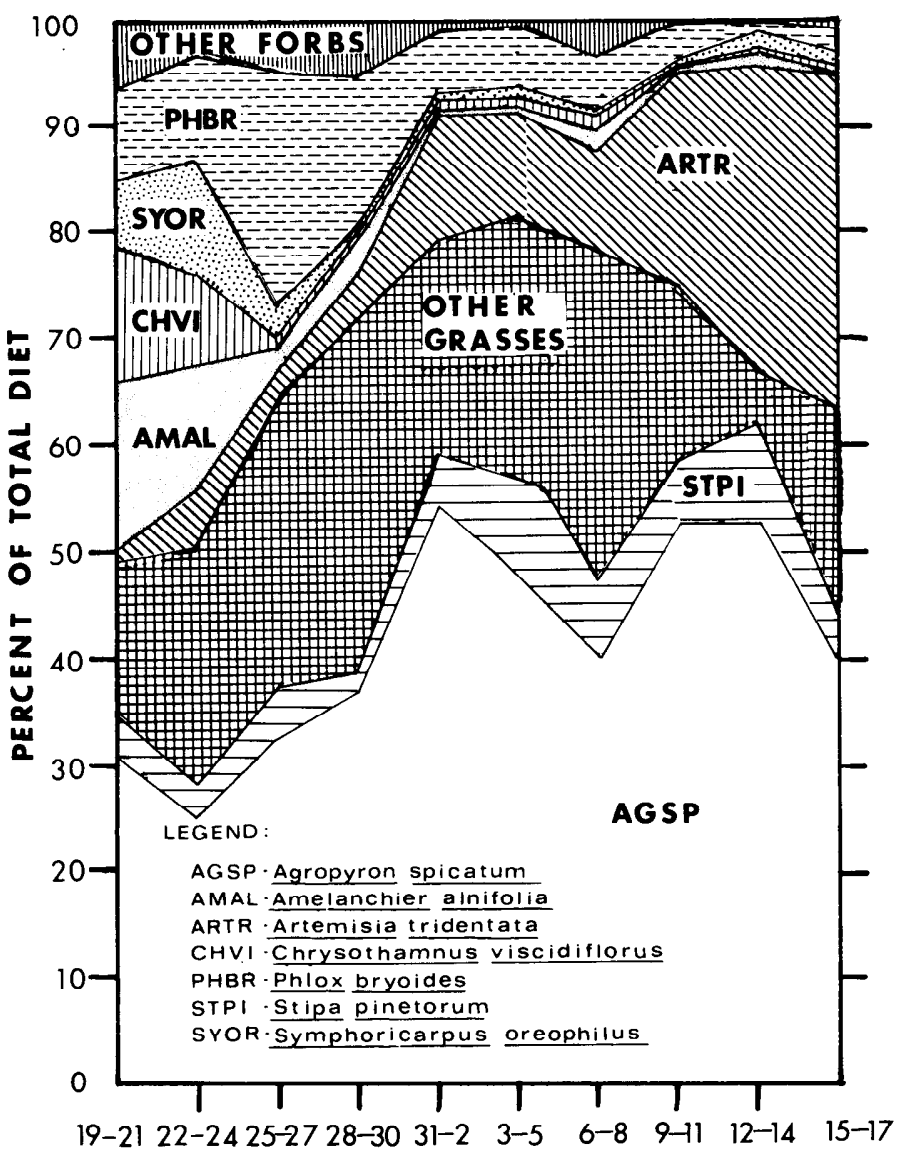

JANUARY FEBUARY

\section{DATE}

Fig. 1. Composition of observed intake for six mule deer at pasture for 30-day period.
A miscellany of species other than grasses and sagebrush made up half the diet initially, but they diminished to $5-6 \%$ of the diet near the end. The few serviceberry shrubs present were browsed avidly from the start until the available current annual growth was removed. The pattern of use of snowberry was similar. Though green rabbitbrush was quite common, most plants had been closely cropped by jackrabbits (Lepus townsendi). The deer removed the remaining stems rapidly and continued to browse on the basal stubs. Phlox was widespread in the pasture. As the use of serviceberry, snowberry, and rabbitbrush decreased, the use of phlox increased, then abruptly dropped as its supplies became exhausted.

Other species-28 in all-comprised about $5 \%$ of the observed intake in the first week and less than $0.5 \%$ in the last week. Though the consumption of species other than grasses decreased rapidly after the first week, the mean number of species in the meais did not change appreciably until 3 weeks had passed (Fig. 2). This suggested that deer were no longer encountering many of the original species while foraging.

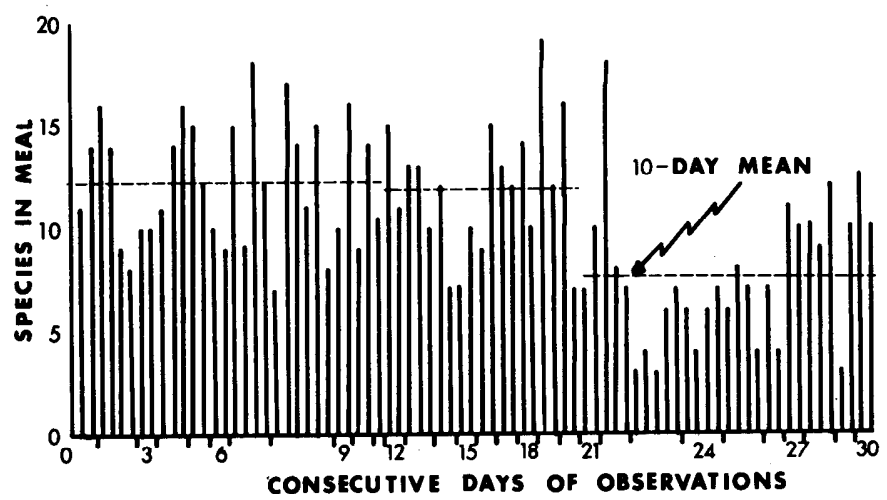

Fig. 2. Number of plant species used in each mule deer meal for 30-day period. A meal is defined as forage consumed during one observation period.

Consumption of grasses increased dramatically in the first 2 weeks, while serviceberry, snowberry, and rabbitbrush consumption decreased. Though sagebrush was abundant, it remained a minor clement in the diet for 2 weeks, then its use increased abruptly (Fig. 1). However, the increase in sagebrush consumption was directed to certain apparently preferred plants (Carpenter 1976). Most of the individual sagebrush plants were

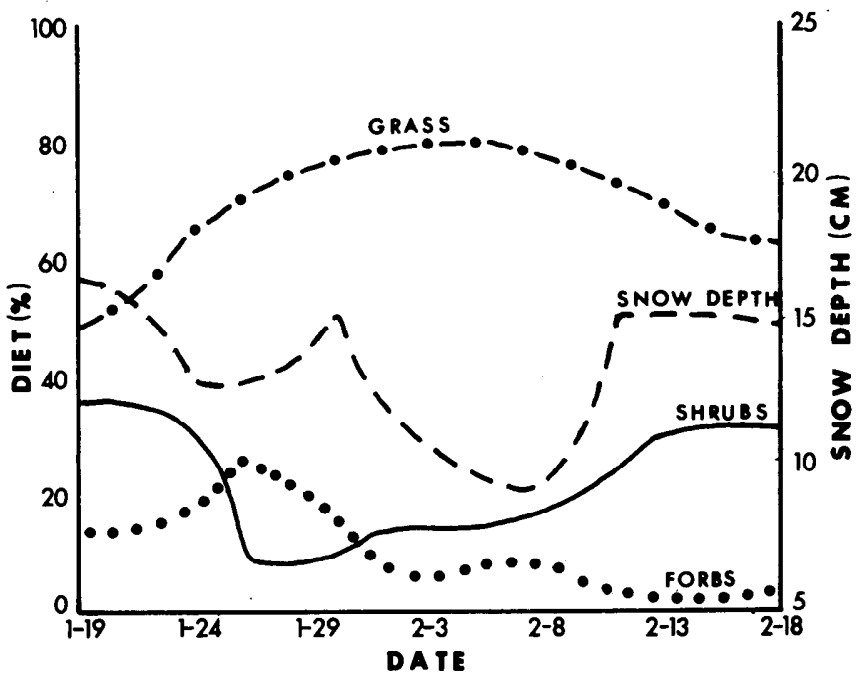

Fig. 3. Relationship of snow depth to diet composition of mule deer at pasture. 
The data also suggest that when snow accumulations limit extent of winter ranges the complexity of relationships between dietary diversity, duration of site occupancy, and snow depth are increased. Generally, as the time of occupancy increases, forage diversity decreases and changes in snow depth modulate the degree and rate of this relationship.

\section{Literature Cited}

Alldredge, A.W., J.F. Lipscomb, and F.W. Whicker. 1974. Forage intake rates of mule deer estimated with fallout Cesium-137. J. Wildl. Manage. 38:508-515.

Carpenter, L.H., O.C. Wallmo, and M.J. Morris 1973. Effect of woody stems on cstimating herbage weights with a capacitance meter. J. Range Manage. 26:151-152.

Carpenter, L.H. and D.L. Baker. 1975. Middle Park deer study-deer habitat evaluation. Colo. Div. Wildl., Game Res. Div. Fed. Aid Proj. W-38R-29. Game Res. Rep. July, Part 2. p. 241-263.

Carpenter, L.H. 1976. Nitrogen-herbicide effects on sagebrush deer range. PhD Diss., Colorado State Univ., Fort Collins. 159 p.

Cook, C.W., and L.E. Harris. 1968. Nutritive value of seasonal ranges. Utah Agr. Exp. Sta. Bull. 472. 55 p.

Dietz, D.R., and L.E. Yeager. 1959. The apparent role of sagebrush in the management of mule deer winter range. W. Ass. State Game Fish Comm., Proc. 39:151-158.

Freeland, W.J., and D.H. Janzen. 1974. Strategies in herbivory by mammals: The role of plant secondary compounds. Amer. Natur. 108:269-289.

Galt, H.D., B. Theurer, J.J. Ehrenreich, W.H. Hale, and S. Clark Martin. 1969. Botanical composition of diet of steer grazing a desert grassland range. J. Range Manage. 22:14-19.

Gill, G.B. 1972. Alterations of in vitro digestibility of deer browse as affected by systematic mixing of paired species. MS Thesis, Univ. Montana, Missoula. 82 p.

Jobman, W.B. 1972. Consumption by juniper by deer and inhibition of rumen microorganisms by volatile oils of juniper. MS Thesis, Colorado State Univ., Fort Collins. 51p.
Leach, H.R. 1956. Food habits of the great basin deer herds of California. Calif. Fish Game 42:243-308.

Longhurst, W.M., H.K. Oh, M.B. Jones, and R.E. Kepner. 1968. A basis for the palatability of deer forage plants. North Amer. Wildl. Natur. Res. Conf., Trans. 33:181-192.

McMahan, C.A. 1964. Comparative food habits of deer and three classes of livestock. J. Wildl. Manage. 28:789-808.

Nagy, J.G., H.W. Steinhoff, and G.M. Ward. 1964. Effects of essential oils of sagebrush on deer rumen microbial function. J. Wildl. Manage. 28:785790.

Nagy, J.G., and R.P. Tengerdy. 1967. Antibacterial action of essential vils of Artemisia as an ecological factor. II. Antibacterial action of the volatile oils of Artemisia tridentata (big sagebrush) on bacteria from the rumen of the mule deer. Appl. Microbiol. 16:441-444.

Neal, D.L., and J.L. Neal. 1973. Uses and capabilities of electronic capacitance instruments for estimating standing herbage. J. Br. Grassld. Soc. 28:81-89.

Nichol, A.A. 1938. Experimental feeding of deer. Univ. Arizona Tech. Bull. 75. 39 p.

Trout, L.E., and J.L. Thiessen. 1968. Food habits and condition of mule deer in Owyhee County. West. Ass. State Game Fish Comm., Proc. 48:188-200.

Ullrey, D.E., W.G. Youatt, H.E. Johnson, L.D. Fay, D.B. Purser, B.L. Schoepice, and W.T. Magee. 1971. Limitations of winter browse for the white-tailed deer. J. Wildl. Manage. 35:732-743.

Wallmo, O.C., and R.B. Gill. 1971. Snow, winter distribution, and population dynamics of mule deer in the central Rocky Mountains. p. 1-15. In: A.O. Haugen (ed.). Proceedings of the snow and ice in reaction to wildlife and recreation symposium. Iowa Coop. Wildl. Res. Unit, lowa State Univ., Ames. $280 \mathrm{p}$.

Wallmo, O.C., and W.L. Regelin. In Press. Food habits, diet quality and nutritional requirements of mule deer and black-tailed deer. CRC Handbook of Nutrition.

Wallmo, O.C., L.H. Carpenter, W.L. Regelin, R.B. Gill, and D.L. Baker. 1977. Evaluation of deer habitat on a nutritional basis. J. Range Manage. 30:122-127.

Wallmo, O.C., W.L. Regelin, and D.W. Reichert. 1972. Forage use by mule deer relative to logging in Colorado. J. Wildl. Manage. 36: 1025-1033.

\section{Membership in the Society for Range Management ...}

is open to those engaged in or interested in the study, management, or use of range ecosystems and the intelligent use of all range resources

includes research scientists, ranchers, governmental agency administrators and technical personnel, teachers, students, people from the business community

provides members with two publications-one oriented to research (Journal of Range Management) and the other oriented to practical resource management (Rangelands)

offers opportunities for face-to-face exchange of ideas at local, national, and international meetings of the Society.
Dues vary according to type of membership and geographical Section. For application forms and additional information. contact the:

\author{
Executive Secretary \\ Society for Range Management \\ 2760 West Fifth Avenue \\ Denver, Colorado 80204 \\ (303) 571-0174
}

